The Joumal of Medical Humanities, Vol. 12, No. 3, 1991

\title{
Stories of Family Caregiving: Case Studies in Moral Reasoning
}

\author{
Suzanne Poirier, Ph.D. and Lioness Ayres, R.N., M.S.
}

Family relationships are complex, interdependent, multifactorial, cultural, and sociopolitical. In instances of family caregiving, the dynamics of these relationships influence the well-being of all members. This paper will address one dynamic of family relationships, moral reasoning, as set forth in the theories of Carol Gilligan. Gilligan's theories about two patterns of reasoning, based on the ethics of justice and care, will be examined within "stories" from fiction and interviews with family caregivers. This examination will raise issues about Gilligan's theories as well as about the literary works themselves and will suggest new ways for health professionals to work with family caregivers.

In 1978 Frank Kermode described literature scholars as "overreaders . . . members of a special academic class that has the time to pry into secrets" (Kermode 1981, 84). Such overreading and prying is an exercise accepted today by the readers of many different kinds of texts. Scholars in the medical humanities have even come to call the patient a "text" to be carefully "read" in terms of both body and word, needing to be "interpreted" in order to diagnose, treat, and feel compassion for (Daniel 1987, Hunter 1991). This paper approaches one aspect of patient care - the care of family members by family members in their homes - from the premise that the texts of both literature and "real life" are mutually enlightening in what they reveal about the nature of family home nursing and effects on all of its participants.

Suzanne Poirier, Ph.D., is Associate Professor of Literature and Medicine in the Department of Medical Education, College of Medicine, University of Illinois at Chicago. Lioness Ayres, R.N.M.S., is a doctoral student in the College of Nursing, University of Illinois at Chicago. Address reprint requests to Suzanne Poirier, Dept. of Medical Education (M/C 591), Univ. of Illinois, P.O. 6998, Chicago, IL 60680. 
Relationships among family members are complex, interdependent, multifactorial, cultural, and sociopolitical. One sociopolitical dynamic of family relationships is moral reasoning, or the way family members define their relationships with each other and justify the behaviors arising from those definitions. While family nursing has long recognized the need for understanding the many, interrelated dimensions of family relationships (Griffin 1980, Doherty and McCubbin 1985), the consideration of the role of moral reasoning in this drama has only recently come under scrutiny.

Central to the study of moral reasoning are the theories of Lawrence Kohlberg (1981), who suggested that the trajectory of moral development moves toward recognizing the rights of other and balancing those rights with one's own. As implied by the word rights, Kohlberg describes moral reasoning as based on a theory of justice that focuses on exchange, weighing what is owed by one person to another. Carol Gilligan (1982) challenged this framework in 1982, when she observed that Kohlberg established "norms" of moral reasoning based only on the reasoning of boys and men. Consequently, she charged, these theories often judged girls and women who did not follow the patterns as deficient or inferior. Gilligan posited that "different" was not necessarily inferior, then went on to demonstrate that many women's and girls' moral development derived from an ethic of care and responsibility rather than one of rights and justice. Although men identify moral duties in terms of the rights of themselves and others, women tend to assign responsibilities based on the contexts of particular relationships. Men generally recognize morality as a hierarchy of duties while women more often understand morality as a web of responsibility and care. Thus, men stress the independence of each moral agent while women focus on the interdependence of the various agents.

Both Kohlberg and Gilligan described this development as occurring in stages which they labeled pre-conventional, conventional, and postconventional. Roughly, a form of pre-conventional reasoning that put one's own needs/rights in the center of one's universe would, if "development" occurred, give way to conventional awareness of and surrender to the needs/rights of one's social group(s), which would ideally lead to an eventual post-conventional balancing of individual and group demands. Within this structure, Gilligan noted that boys had more problems, from their justice-based mode of reasoning, in moving from a self- to a group-centered ethic, while girls often found it difficult to re-assert their individual needs once they identified themselves as a group member. This second situation is the "trap" of self-sacrifice in which Gilligan found many women caught and paralyzed. Societies often praised such self-effacement in women, she found, while women often lost all sense of self, making it difficult to even 
identify one's needs, let alone begin to balance them with the needs of others.

Although Gilligan has recently revised her thinking about "stages" of moral development and is less willing to chart identifiable, linear movement of women from one stage to another (1988), descriptions of the development of moral reasoning remain chronological and evolutional. It is a psychological story, with desire, conflict, change, and (often) catharsis. As such, it shares many of the same elements of fictional stories. The discussion that follows draws upon the narrative similarities of fiction, patient interviews, and Gilligan's theories to explore the experience of family home nursing. Two novels from nineteenth England and the United States are paired with two interviews of a man and a woman who have each been the primary caregiver for their spouses for, respectively, 11 and 14 years. By examining how characters as well as actual family members talk about themselves or act in a caregiving role we can come to discover, to use Kermode's terms, the "secrets" of how they reason about their family, their world, and their place in both. This literary exercise, moreover, will return us to Gilligan's ideas with a new understanding of care, new interpretations of the two novels presented here, and a new approach for health professionals who work with family home caregivers.

\section{ETHAN FROME, MR. D, AND INDIVIDUAL RIGHTS}

Ethan Frome was written in 1911 by Edith Wharton, a New England writer who was interested in the psychologies of characters alienated within their societies. Although many of her novels are set in Victorian and turn of the century, affluent New York society, with Ethan Frome she deliberately set out to explore the influence of place. "I had had an uneasy sense," wrote Wharton in her preface to Ethan Frome, "that the New England of fiction bore little - except a vague botanical and dialectical - resemblance to the harsh and beautiful land as I had seen it. . . that the outcropping granite had . . . been overlooked" $(1911$, v.). In this novel Wharton describes oppressive duty and its eventual destructive outcome for characters whose abortive aspirations are stifled economically, socially, and geographically by their isolated family and community life.

Ethan Frome was born in Starkfield, a grim New England village that was bleak even in the gentlest of seasons and defenseless against the implacable winters of the region. Families cared for their own. There were no other resources. Ethan was no exception. A bright and talented though inarticulate - youth, Ethan left college when his father "got a kick, out haying, and went soft in the brain" (8). Next, his mother "got queer 
and dragged along for years as weak as a baby" (8), necessitating the addition to the family of Ethan's cousin, Zenobia, to help with the nursing. Zenobia and Ethan married after the death of Ethan's mother but Zenobia (called Zeena) developed a series of chronic but ill-defined ailments, becoming a complaining, selfish, unloving and unlovable "invalid," who in turn needed help at home. (Zeena's story may well have "secrets" of its own that explain, more sympathetically than is generally presented here, her own bitterness and invalidism.) This time, the Fromes enlisted Zeena's cousin, Mattie. Mattie, however, didn't fit the Starkfield mold. She was cheerful, agreeable, voluble, energetic. More important, although Ethan was too inarticulate to tell her his feelings, Mattie seemed to know and understand his heart. When Zeena sensed Ethan's growing love for Mattie, she engineered Mattie's removal, defending her actions in terms of her needs as a sick woman.

Ethan and Mattie had no choice. Conventional social duty required that Ethan abandon Mattie. She had no claim to him because, after all, "Mattie was [Zeena's] relation, not his: there were no means by which he could compel her to keep the girl under her roof" (58). Finally, in a longpromised sled ride, Ethan and Mattie saw their only option: they steered into the old elm tree at the bottom of the hill.

The true moral of the story is the triumph of oppression and duty. Mattie and Ethan hit the tree, but did not die. Ethan was badly injured but survived to work his threadbare farm. Mattie was paralyzed and, worse, transformed into the querulous recipient of Zeena's equally querulous care. The triumph of duty meant the living death of Ethan and all the members of his family. Ethan is never heard complaining to the first person narrator of the novel, but other characters pass judgment on his plight. Wharton gives the novel's last words to the kindly Mrs. Hale, who observed to the novel's narrator, that if Mattie "'ha' died, Ethan might ha' lived; and the way they are now, I don't see much difference between the Fromes up at the farm and the Fromes down in the graveyard; 'cept that down there they're all quiet, and the women have to hold their tongues"' (88).

Although Ethan, Mattie, and Zeena lived as a family, their circumstances separated them from their community and from one another as effectively as tombs. Ethan, Zeena, even Mattie respected the ethic of justice as they understood it; each lived - unremittingly - according to his or her duty to family. Ethan worked the farm, Zeena tended the invalid, Mattie ailed. Within this rigid conventional ethic of rules, the ethics of care found no place. It not only is not, but seemingly should not be considered. One's obligation to one's family is the only consideration. Without a web of caring, each member in Ethan's family suffers. 
As a contrast, we find Mr. D, who also was concerned with duty and obligation. Although he was less economically and emotionally oppressed by his situation than Ethan Frome, he was equally confined. Mr. and Mrs. D had been married for 45 years when Mrs. D was disabled by a stroke. For eleven years, she has remained at home, unable to speak, move, or swallow. Asked to describe her physical limitations, Mr. D replies, "She's a veg - she's dead, all she does is breathe." A tube into her stomach feeds her and another drains urine from her bladder. He turns her immobile body, side to back to side, every two hours. He has turned her every two hours for eleven years, except at night when, according to Mr. D, he "cheats a little bit." For eleven years, Mr. D's life has been governed by a single moral imperative, described in his own words: "She took care of me for forty-five years; now I'm gonna take care of her."

Mr. D is emphatic and unambiguous in stating his theme. He takes charge of the interview from the beginning ("All right, start asking questions"), and his responses leave little doubt that other well-meaning professional women have asked him these questions before. He sits, barely able to contain himself, until the introduction to the interview is completed and then bursts out:

Mr. D: I got one answer, I got one answer, I got one answer that'll cover everything.

Interviewer: What is that?

Mr. D: Like I told [my sister-in-law] and them two [visiting family members from out of state] this morning, she took care of me for 45 years and I can take care of her. That covers everything.

And so it does. Mr. D's life is governed, dominated by the autocratic demands of his duty to his wife's body. Although he lives in a suburban bunglow instead of a New England farm, Mr. D. has no more opportunities for a social life than did Ethan Frome. As far as Mr. D is concerned, the local movie theaters, shopping malls, miniature golf courses, and bowling alleys might as well be buried in snow and ice.

Mr. D's Mediterranean zeal was easy to mistake for irritation, and the first part of the interview seemed very stiff and formal, as Mr. D. answered questions about his wife's illness, her hospital course, her brief and unsatisfactory stay in a nursing home, the routines of her carer at home. When the interview shifted to questions about Mr. D's perceptions and experiences of caregiving, however, the tone of his responses changed markedly. For example,

Interviewer: If you had to describe what it's like for you to do this, how would you describe it?

Mr. $D$ (a pause, the first one since the interview began): Gee, now that's a hard question ... I don't even know how to answer that one. 
Interviewer: Pick a word, or a couple of words.

Mr. $D$; Rough. It's been rough.

And here Mr. D begins to talk, in a way never possible for Ethan Frome, about the difficulties and burdens of caregiving. The interview continues:

Interviewer: How has it been rough?

Mr. D: Well, it's a, you can't go anyplace, you can't do anything . . .

Later in the interview, asked what he thinks is the hardest part of caregiving, he answers, "Well, this is gonna sound crazy. You can't, you can't get, you can't just get up and go away for a day or so that's - forget it, you can't do that. And that, to me, that's hard, because I'm used to . . . bummin' around a little bit, you know, I used to go on trips, but now, forget it."

Mr. D is not entirely isolated. In order for him to grocery shop, his sister-in-law visits once every two weeks and stays with Mrs. D. More distant relatives visit occasionally. The D's only child, Sonny, aged 56, lives at home and helps in some unspecified capacity to care for Mrs. D. He lives at home, doesn't work, and visits a local hospital daily for an unnamed "therapy." Although he was present in the home during the interview, he didn't come into the room or speak.

Mr. D, like Ethan Frome, doesn't complain. His burdens, his fears, his guilt may never have been aired before. When asked what the experience of the interview was like for him, Mr. D responded, "I liked it ... You gave me a change to get something off my chest which I've had for a long time." Ethan Frome never utilized such an opportunity.

Like Ethan Frome, Mr. D has lost the woman he loved. Like Mattie, Mrs. D's illness has transformed her. Both Mattie and Mrs. D survived their accidents (Mr. D calls the stroke "a major hit"), but their romantic relationships did not. Mr. D is entirely unsentimental about his wife's present state. Asked if he thinks his wife knows where she is, or that he is present, he replies, "I don't know. I haven't the least idea." Neither is he sure if she is comfortable or in pain: "She don't have no feelings, I don't think." This being the case, what benefit is home care bringing to his wife? "There ain't many benefits there. She's not benefitting any way." Not only that, but Mrs. D - the "real" Mrs. D who is no longer present - would abhor her current existence every bit as much as the gay, dancing Mattie abhors her paralysis. Mr. D comments, "She was lively ... If she knew what she was goin' though, one way or the other she wouldn't put up with it. That's the type of girl she was. I ain't doing her no favor."

Then, why? Why feed and water and turn this husk to the exclusion of all other activities, all pleasures, for eleven years? Mr. D does it all out of essential, uncomplicated duty. From these narrow, monotonous months 
and years Mr. D identifies only one benefit: "I get the satisfaction of seeing she's nice and clean ... That's what I like." Forty-five years of care bind the Ds to their present life just as familial duty bound Mattie and Ethan to Zeena. And both Ethan and Mr. D can guess why they are suffering. Says Mr. D, "When I see her in the mornin' sometimes I do a little swearin' 'cause she was, she was, you couldn't tie her down no way when she was well ... I wonder that the guy upstairs, what he's tryin' to prove." When asked what he thinks the "guy" is trying to "prove," Mr. D answers, "He's punishing us. Why?"

Given a moral framework built on justice and duty, no other conclusion for either Mr. D or Ethan Frome is reasonable. A man gets the life he deserves. Ethan knows that his and Mattie's miserable lives are the consequence of bad moral choice: he denied his duty to Zeena, choosing instead romantic love. But what did the Ds do? What are they being punished for? Is it something about Sonny? Some early indiscretion? Something darker? Lacking the omniscient narrator, we cannot know. Ultimately Mr. $D$ keeps his secret - maybe even from himself - and the daily realities of invalid care, a duty accepted but unalleviated by any sense of personal benefit or reward.

\section{JANE EYRE, MRS. W, AND THE EVOLUTION OF CARING}

Charlotte Bronte's Jane Eyre shows a more complex drama of moral reasoning. In the words of the author, we recognize a distinction that clearly presages the words of Kohlberg and Gilligan over a century later: "conventionality," Bronte asserts, "is not morality" (1947, v-vi). This statement captures the spirit of what Kohlberg and Gilligan (in her earlier writing) refer to as post-conventional reasoning, that is, reasoning that strives to consider and balance the needs and demands of oneself, others, and one's social community. In such an equation state, religious, or common laws are only part of the configuration.

Jane Eyre, published in 1847 , has been read with new eyes in the past twenty years. Traditionally, the novel was read as a romantic, somewhat gothic tale of the plain, orphaned governess whose goodness prevails over her formerly dissolute but nevertheless desirable employer. Jane's "triumph" to many readers today is seen as a capitulation from her earlier arguments against marriage and her development of autonomy, self-worth, and common sense. The novel is often read as Bronte's attack on her repressive society, which held women slave to 
their sexuality while forcing them at the same time to repress it (Gilbert and Gubar 1978, 359-362).

Jane Eyre begins with the orphaned Jane living in the home of her Aunt Reed, where Jane was unloved and mistreated. When Jane was finally able to escape this prison to go to school, she left with relief and anger, vowing, "I will never call you aunt again as long as I live. I will never come to see you when I am grown up .... Y You think I have no feeling, and can live without one bit of love or kindness; but I cannot live so" (36). Although Jane desired love, she met its absence with "preconventional" logic in which self-protection comes first. If any conventional ethic influenced Jane, it was the rules based one we saw in Ethan Frome, which stated that families had "obligations" to each other but that love was not necessarily a part of the contract.

Jane departed for Lowood school, where life was harsh and injustice abounded. But Jane learned to survive. As she found friends and was accepted into their circles, she began to move into more "conventional" stages of reasoning. For the first time, she allowed herself to care for others. This development continued after Lowood when she was accepted into the community and confidence of the residents of Thornfield Hall, where she was hired as governess. That community soon extended to her employer, Mr. Rochester, grew into love, and culminated in Jane's engagement to him. Jane's joy was shattered, however, on the day of her wedding, when she discovered that living in the attic at Thornfield, watched over by a hired keeper, was Mr. Rochester's "mad" wife, Bertha Mason.

Feeling he had "done his duty" in caring for his wife, Mr. Rochester desired Jane to exchange with him "a pledge of fidelity" (357), a marriage without benefit of clergy. Jane, however, followed the dictates of convention and refused, forfeiting love to social mores. Her defense can be interpreted as a "conventional" care based ethic, in which Jane accepted the rules of her society and effaced her own needs: "Laws and principles are not for the times when there is no temptation," she stated, "they are for such moments as this .... Preconceived opinions, foregone determinations, are all I have at this hour to stand by; there I plant my foot" (359). This is the trap of self-abnegation and -sacrifice described by Gilligan in In a Different Voice.

Quietly, before dawn, Jane left Thornfield. As a result of her precipitous flight, Jane collapsed on the steps of Moor House, where she was taken in by the kindly Mary and Diana Rivers. Through one of those strange coincidences popular in the nineteenth century novel, Jane and her readers discover that Jane was cousin to the sisters and their brother, the saintly clergyman St. John. For the first time in her life, Jane was a member 
of a family united both by kinship and by care. Thus, when St. John asked Jane to marry him and join him as a missionary in India, she found joy in an opportunity to help him but replied, in an ironic inversion of Rochester's proposal to her, that she would accompany him as his kinswoman only. Having known love, Jane refused to marry without it. Such a position was untenable to the conventionally moral St. John, but Jane defended her position in the language of Gilligan's (again, from her early writing) "postconventional" caring, balancing St. John's need for companionship with her own desire to help him and her refusal to marry without love. In such an equation, social roles and conventions rang hollow; "conventionality" as the author had stated in her preface, was certainly "not morality" in this stage of reasoning. Where Jane, unsure of her own mind and strength, had conceded to social "laws and principles" only a few months earlier, she now had the strength and self-confidence to rise above them. In response to a psychic call for help, Jane left Moor House to join Rochester whatever his situation.

As Jane moved along the continua of both justice and caring, she rejected both the masculine reasoning of rights and the self-abnegation of feminine sacrifice, the latter especially deadly in the limited views of women's roles in the 19th century. One may continue to doubt the wisdom or beneficence of a society that created or condemned Bertha Mason, just as one can recognize that the final union of Jane Eyre and Edward Rochester is traditional but incongruous. But Jane herself does not define love in general or her love with Rochester in the conventional romantic terms of her times. Rather, she speaks of a love that recognizes pain as well as joy and which is realized through conscious decisions. In the end, duty to one's actual or chosen families does not weigh as heavily as care given unconditionally through love.

Mrs. W, like Jane Eyre, tells a story whose decisions reflect a changing pattern of moral reasoning. Mrs. $\mathrm{E} \mathrm{W}$ is a forty-two-year-old mother of two children who cares for her husband, $\mathrm{J} \mathrm{W}$. $\mathrm{J}$ has been ill continuously since 1974, when he developed multiple intestinal problems that led to an episode of acute blood poisoning. He was diagnosed with Crohn's disease (an inflammatory disease of the bowel). In spite of medical treatment, Mr. W continued to feel exhausted and weak and was unable to return to work. In January of 1979, after a long and complex diagnostic course at several medical centers, Mr. W's illness was finally identified as "inclusion body muscular dystrophy." Since then he has become progressively more disabled. At the time of the interview, J W was totally bedbound, breathed through a tracheotomy incision in his throat, and was limited physically to the use of his remote television control and an oral suction catheter. Mrs. $\mathrm{W}$ works full time as a lab technician. During the day, Mr. W is cared for 
by a homemaker, supplemented by the W's teenaged children during the summer.

Mrs. W described two moral decisions that closely resemble decisions made by Jane Eyre. The first was the decision to care for her husband at home. Mr. W's first episode of acute illness began, according to Mrs. W, on the day she came home from the obstetrician's office knowing she was pregnant with their first child. At that time they had been married barely two years. Asked why she decided to care for her husband, Mrs. W responds that she had made a marriage vow in the Roman Catholic Church and believes that she is therefore obliged to care for her husband in all circumstances. Mrs. W's decision to become a caregiver, based on her marriage vows, is an example of a "conventional" caring decision. Mrs. W never mentions the justice or fairness of the decision, but instead sacrifices her dream of an ideal marriage for a commitment to the conventional societal expectations represented by her religion.

Mrs. W clearly understands that she has made a sacrifice. She describes the impact of her husband's illness on their relationship and on her life:

I have ideas in my mind what a quote normal marriage should be and I don't have that or never did have that. We have our religious background and you're joined together in the church and so I think that a normal relationship would be that you're joined together in all things: in caring for your children, in caring for the house ... I think ideally a nice relationship would be shared responsibilities in the house, in the home, taking care of the yard ... and I've just never had that.

Mrs. W's moral reasoning in this case is based entirely on care and responsibility, words she uses often in describing her role, along with the word commitment. She says she never questioned that she would care for her husband and has angrily rejected any suggestions that she not do so, even though she feels that the care she provides is about as good as, but not better than, the care he would get in a nursing home.

Mrs. W's reasoning resembles Jane Eyre's decision to leave Rochester. Like Jane, Mrs. W recognizes that her decision has eliminated the possibility of marriage as she understands it, and that her subsequent quality of life will be less than she had hoped. Similarly, she does not justify her decision with the belief that her husband's well-being is enhanced by her caregiving, in the same way that Jane knew that Rochester would be no better for her leaving Thornfield Hall. The decision for both is grounded in duty of self-sacrifice, and both suffer for it, accept their suffering as appropriate, and make the best of it.

Mrs. W makes a second decision in a less conventional way, but like Jane uses an ethic of love and self care in her reasoning. For Jane, the "post-conventional" decision was to reject a passionless marriage to St. 
John. Jane struggled with this decision, and endured harsh criticism from St. John, but held fast. Mrs. W was also faced with a difficult decision. Mr. W had recently been putting pressure on his wife to resume some sort of physical intimacy with him. Mrs. W finds that physical intimacy is inconsistent with the responsible caring relationship she feels has replaced "normal marriage" for her and her husband. She says,

I don't mind saying it, personal and physical intimacy is-it's just not there. It's not what you would want it to be and that has brought on added emotional problems because although I can't say a lot to him because I just can't bring myself to hurt him any more but it is extremely hard. In my situation where you're caring for a spouse and a person that needs as much care as he does, it is extremely hard, it is extremely emotionally hard, it is emotionally overwrought for me to care for him in the way that 1 have to care for him and then be a physical partner for him. I can't do it. I can't do both.

The conventional moral response would be for Mrs. W to stifle her feelings and do her wifely duty, just as for Jane the conventional response would be to marry St. John and go to India. Like Jane Eyre, Mrs. W recognizes that such a decision would involve betraying herself, and like Jane this time she incorporates her own needs into the moral decision-making process. At the same time, she recognizes the needs of her husband. Mrs. W does not share her moral reasoning with him, because it would cause him added pain. She says, "I would not want to say [this] to him because I would not want to hurt his feelings but a lot of times the mother instinct in me comes out extremely strong and I just can't cross that barrier from being mother to him and being intimate to him."

Unlike Jane Eyre, Mrs. W has not always been alone in making major moral choices. The Ws recently decided to enroll in hospice care, with the aim of palliation rather than cure. Concomitantly, they have decided that when Mr. W next develops respiratory failure, he will be treated supportively but that treatment will stop short of mechanical ventilation. Thus it is likely that his next episode of respiratory failure will prove fatal. Mrs. W made this decision based on minimizing J's suffering and/or receiving the support from many members of her network of relationships. She recounts,

[I]t was three months ago, $J$ was having a real hard time breathing and I was up a lot every night and he - it was another crucial period when I just didn't know how I was going to keep on managing and I got a magazine and there was a very long article ... about ventilator-respirator situations and one of the points that was brought out was that if a person could go on the respirator for the evening, the nighttime hours and get rejuvenated it would maybe help the patient through the day. And so I approached Dr. $C$ with that and it was after much discussion that he helped me realize that in J's case it could not be the best thing for him to go on a respirator. We had talked about it before ... and $J$ had said that he never wanted to go back on the respirator and so it took Dr. C talking to me and he was very supportive but he said, "you know that isn't what you both really want. 
he was very supportive but he said, "you know that isn't what you both really want. You're trying to reach out for that now because you're so very tired." So after that I called [the nursing agency] and talked to the social worker . . . and it was at that point between [the social worker] and our priest from church that $J$ understood the situation and he then went and signed a Living Will and we got under hospice.

Mrs. W's network of relationships here includes herself with her need for relief, her husband's desire not to be placed on a respirator, the physician's judgment of both the medical and the personal consequences of Mr. W's illness, the social worker from the hospice program, and the priest. The choice of hospice was one that suited the aims of all these people, and Mrs. W is in no way troubled by her decision.

Both Jane Eyre and Mrs. W evolve, in the course of their stories, a moral reasoning that incorporates the needs of those they love with their own, individual needs. This process includes setting boundaries around one's own limits of living, as Jane refuses to marry St. John and Mrs. W will not resume a sexual relationship with her husband. Such limitation is not rejection, however, as Jane remains in touch with her new-found family and $\mathrm{E}$ and $\mathrm{J} \mathrm{W}$ are able to make decisions mutually about hospice and living wills. Moreover, each woman came to her last documented position through confronting and rejecting previously accepted personal and societal beliefs, in Jane's instance personal beliefs against marriage and social rules about monogamy and in Mrs. W's case her personally held and socially assumed expectations of a wife's sexual obligation to her husband.

\section{DISCUSSION}

We cannot say, however, that either Jane Eyre or Mrs. W have "completed" their moral development just because they have arrived at a spot that can be described as the "post-conventional" stage of moral development. Jane's "story," it is true, ends at this point, but even in fiction the concept of ending is arbitrary and never final (as any fan of Rocky, the Karate Kid, or Indiana Jones will testify). And, certainly, Mrs. W's life will continue. There is, within neither of these "stories," the assurance that new circumstances or new demands will not produce new ways of grappling with their dilemmas. And there is no way to assume that these new ways will continue to be a complex balancing and reasoning about the needs of everyone. Changes in financial situations, support systems, or the continued passage of time will provide an ever inconstant environment. Thus, although we can see in both the literary and clinical stories presented here examples of behaviors and thinking that correspond to the stages of moral development described by both Kohlberg and Gilligan, we 
would hesitate to declare as permanent, irreversible, or immutable any of these developments.

In addition, while the characters and people presented here in general tend to follow the gender patterns set forth by Gilligan, these distinctions also tend to blur, especially as women like Jane Eyre and Mrs. W "sacrifice" themselves to justice-based ethics or men like Ethan Frome and Mr. D also "lose themselves" in their rules-based logic. In other words, both sophisticated literature as well as real life with all its complexities demand that we look carefully at our use of such terms as "development," "change," "evolution," and "adaptation." Moreover, before applying labels or passing judgment on characters' or people's actions it becomes necessary to consider the cultural, psychological, economic, and temporal contexts in which individual reasons are voiced and actions taken. When interpreting literature, this means taking care not to judge characters entirely from the perspective of the reader's time or situation. For example, an interpretation of Jane Eyre can both reflect a 1990s skepticism yet recognize the careful, reasoned choices Jane made given her circumscribed world. In health care, we can realize the tenuous relationship between circumstance and moral stance. For example, a hospice worker should be prepared for the possibility of Mrs. W's hard-won balance between her needs and her husband's needs capitulating when the actual event of Mr. W's last weeks or days of life arrive. Similarly, health professionals can realize that each type of moral reasoning contains points of vulnerability for the family home caregiver. They should, for example, look beyond the steady assurances by Mr. D that he has everything under control with the knowledge that positions of self-sacrifice are often ultimately self-destructive.

In summary, how family members reason about their relationships to each other and the moral consequences of those relationships have immediate relevance for how health professionals work with patients and their patients' families - whether a physician in an intensive care unit, a social worker formulating a discharge plan, or a home health nurse paying weekly visits to a husband for his comatose wife of over 50 years. By discovering how their patients perceive familial relationships and responsibilities, practitioners can best respond to the changing needs of both care givers and care receivers. But change is also important. Whether or not individuals "grow" in their moral reasoning, their perceptions of their role within their family are likely to change as circumstances both within and outside their family change. These are the "secrets," some obvious, some often only hinted at, and some sensed but perhaps never discovered, that readers of the "texts" of people's lives are called upon to discover in order to interpret fully and fairly the stories they encounter on the printed page, in the hospital, or in private living rooms and bedrooms. 


\section{REFERENCES}

Bronte, Charlotte. 1847. Jane Eyre. Rpt. New York: Washington Square Press, 1960.

Daniel, Stephen A. 1987. "Literature and Medicine: In Quest of a Method." Literature and Medicine 6:1-12.

Doherty, W. "Families and Health Care: An Emerging Area of Theory, Research, and Clinical Intervention." Family Relations 34:5-11.

Gilbert, Sandra M., and Susan Gubar. 1978. The Madwoman in the Attic: The Woman Writer and the Nineteenth Century Literary Imagination (New Haven, Conn.: Yale University Press).

Gilligan, Carol. 1982. In a Different Voice: Psychological Theory and Women's Development. Cambridge: Harvard University Press, 1982.

et al. Editors. 1988. Mapping the Moral Domain: A Contribution of Women's Thinking to Psychological Theory and Education. Cambridge: Harvard Center for the Study of Gender, Education, and Human Development, Harvard University School of Education, distributed by Harvard University Press.

Griffin, S. J. 1980. "Physical Illness in the Family." In Family Focused Care, edited by J. Miller and E. Janosik. New York: McGraw-Hill.

Hunter, Kathryn. 1991. The Patient as Text. Princeton, N.J.: Princeton University Press.

Kermode, Frank. 1981. "Secrets and Narrative Sequence." In On Narrative, edited by W. J. T. Mitchell (Chicago: The University of Chicago Press).

Kohlberg, Lawrence. 1981. The Philosophy of Moral Development. San Francisco: Harper and Row.

Wharton, Edith. 1911. Ethan Frome. Rpt. 1970, New York: Charles Scribner's Sons. 